\title{
St Paul's Footbridge, Ebbw Vale, Wales—landmark structure
}

\section{E. Williams BSc, CEng, MICE, MIHT}

The paper outlines the design processes involved in the creation of St Paul's Footbridge, a new landmark footbridge at Ebbw Vale, South Wales. The provision of a landmark footbridge forms part of the council's broader strategy to stimulate recovery and regeneration of this area through delivery of quality urban infrastructure design. Regular effective communication throughout the team, drawing on the creative flair of an artist and practical expertise of contractor and fabricator, resulted in a striking structure being delivered for the Ebbw Valley. The team and framework set up to deliver the footbridge and the constraints affecting the design and construction of the bridge are described. The parameters that affected the design of the deck and its foundations together with the fabrication/erection issues that were encountered are also presented. Finally, some factors to be considered when designing infrastructure projects for disabled access are reported.

\section{INTRODUCTION}

Steelwork has once again transformed the landscape of the Ebbw Fawr valley in South Wales. A new landmark structure, St Paul's Footbridge, constructed as part of the Cwm Relief Road scheme, marks the dawn of a new era for this historic area (Figs 1 and 2).

Ebbw Vale stands at the head of the Ebbw Fawr river and is the administrative centre of Blaenau Gwent County Borough Council. For over two centuries coalmining and steel-making had been the backbone of the economy but in 1989 coalmining ceased in the valley and the closure of the steelworks in 2002 brought its iron and steelworks era to an end.

Regeneration has already started in this community. The Cwm Relief Road, which forms part of the council's plan to improve the strategic highway network and attract inward investment, was completed in 2005. The provision of a landmark footbridge at Cwm forms part of the council's broader strategy to stimulate recovery and regeneration through delivery of quality urban infrastructure design.

The Cwm Relief Road was funded through a Transport Grant and was procured under the ECC New Engineering Contract Option D Target Cost Contract. The tender design for St Paul's Footbridge was a contractor design based on a standard vierendeel truss deck with simple concrete pad foundations. The tender footbridge replaced an existing structure and crossed over the existing single-track railway and new relief road. During the construction of the relief road additional funding was secured from the Welsh Development Agency and Blaenau Gwent County Borough Council (the client) to provide a gateway structure to replace the tender design proposal.

This paper reports on: the historical context and outlines the need for a landmark structure; the specialist team and framework set up to deliver the project on a fast-track basis; the importance of good communication in the delivery of complex infrastructure projects; the constraints affecting the design and construction of the bridge; the parameters that affected the design of the deck and its foundations and fabrication/erection issues; and factors to be considered when designing infrastructure projects for disabled access.

\section{PROJECT TEAM}

A project team, as detailed in Table 1, was set up to deliver the structure within the framework of the Cwm Relief Road construction contract (the Construction Contract). The project team included: the client, Cardiff Bay Arts Trust (CBAT), the artist Andrew Rowe and Capita Symonds. In addition to providing a replacement structure, the main brief was to achieve a significant work of public art that could be integrated into the local landscape. The project benefited from a multi-discipline approach with the integration of different team skills utilised to resolve issues as the design evolved. Regular meetings were held to plan, monitor and review the progress of the project throughout.

Of particular interest was the interaction between the artist and the structural engineers. The first ideas developed by the artist (Fig. 3) presented his vision. This was to create a dynamic structure that reflected and worked with the dramatic local landscape. Detailed review of these proposals, however, identified that the proposal could not be delivered within the available budget. Interaction between the artist and the structural engineers during the development phase ensured the artist's concepts and vision were translated into a workable and technically feasible structure (Fig. 4).

Quotations were invited from steelwork fabricators for this design but the prices submitted exceeded the budget by $£ 130$ 000. The design was modified without significantly 


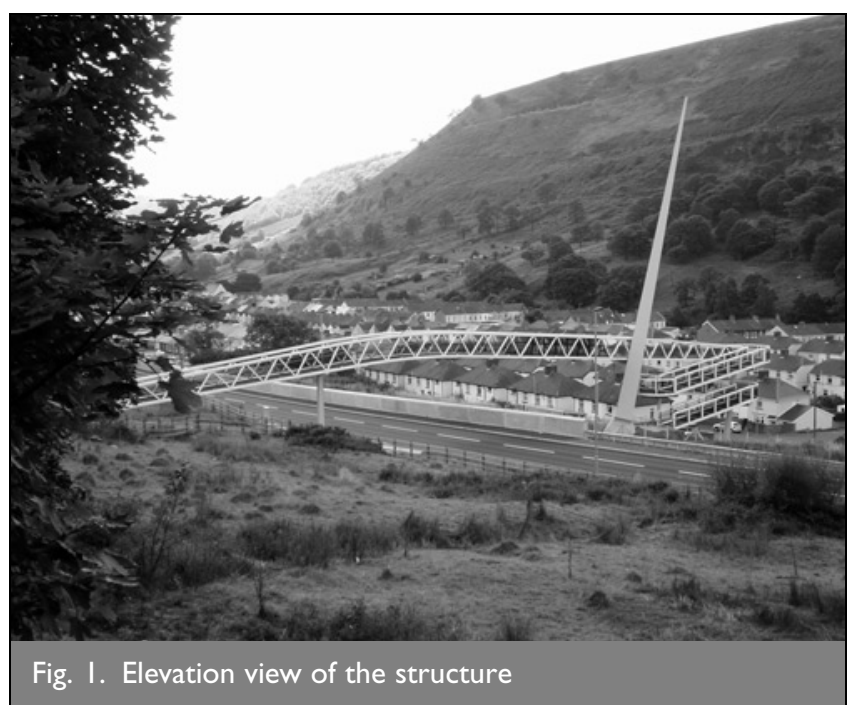

compromising the artist's original concepts (Fig. 5) and the revised steelwork prices then brought the footbridge proposal within budget.

\section{CONSTRAINTS}

The evolution of design from the tendered contractor design footbridge to a significant bespoke structure had to occur within the framework of the existing construction contract and to the available budget of £570 000. The design, fabrication and erection were on the critical path for the main scheme and this imposed tight constraints on time and resources. The design commenced in September 2003 and the steelwork had to be erected in March 2004 to avoid delays and disruption to the construction contract.

Under the construction contract, the main contractor and the steelwork fabricator developed a partnering arrangement to ensure the successful procurement and installation of the footbridge.

A separate team was set up to drive the detailed design process forward. The design team comprised the fabricator, artist, project manager, substructure designer and superstructure checker. The fabricator designed the deck while all other elements were designed or checked by Capita Symonds. The project manager

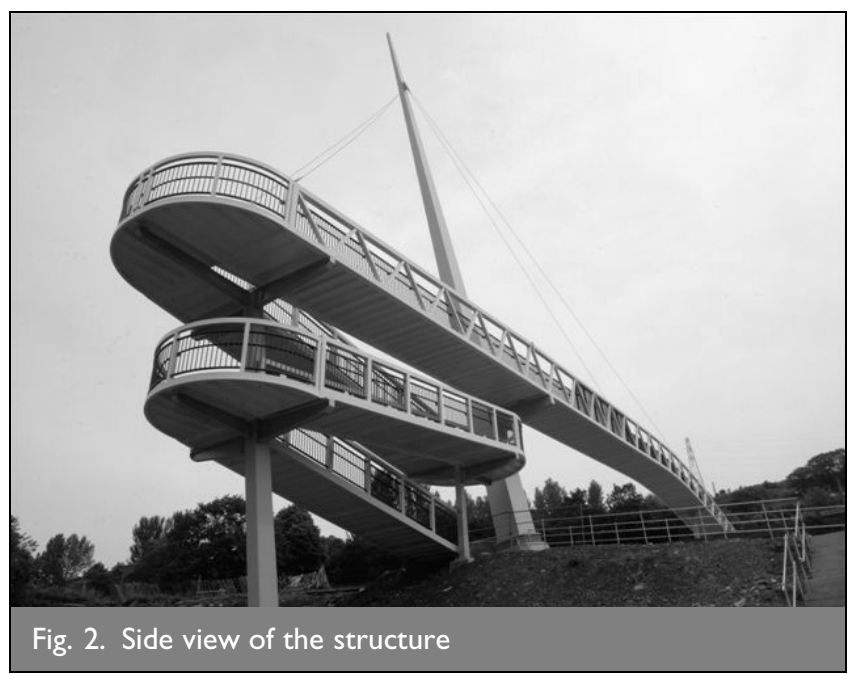

\begin{tabular}{|c|c|}
\hline Participant & Role \\
\hline Welsh Assembly Government & Transport Grant funding. \\
\hline $\begin{array}{l}\text { Blaenau Gwent County } \\
\text { Borough Council }\end{array}$ & $\begin{array}{l}\text { Client and additional funding for } \\
\text { the landmark structure. }\end{array}$ \\
\hline Welsh Development Agency & $\begin{array}{l}\text { Additional funding for the } \\
\text { landmark structure. }\end{array}$ \\
\hline Capita Symonds & $\begin{array}{l}\text { Consultant and client } \\
\text { representative for the Cwm } \\
\text { Relief Road scheme, designer } \\
\text { and checker of the footbridge } \\
\text { substructure and checker for } \\
\text { the superstructure. Project } \\
\text { manager and structural } \\
\text { engineers for the footbridge } \\
\text { design. }\end{array}$ \\
\hline Rowecord Engineering Ltd & $\begin{array}{l}\text { Fabricator. Design, fabrication } \\
\text { and erection of the } \\
\text { superstructure. }\end{array}$ \\
\hline Mowlem plc & $\begin{array}{l}\text { Contractor for the Cwm Relief } \\
\text { Road scheme. }\end{array}$ \\
\hline $\begin{array}{l}\text { Cardiff Bay Arts Trust (CBAT) } \\
\text { The Arts \& Regeneration } \\
\text { Agency }\end{array}$ & $\begin{array}{l}\text { Advice on artist brief and } \\
\text { selection, specialist support } \\
\text { for project manager and } \\
\text { design coordinator and } \\
\text { advice on arts and } \\
\text { regeneration. }\end{array}$ \\
\hline Andrew Rowe DAR Design & $\begin{array}{l}\text { The artist. Concept design and } \\
\text { specialist input into } \\
\text { construction design. }\end{array}$ \\
\hline
\end{tabular}

Table I. Principal participants in the scheme

provided the communication link between the design team and the project team.

The design, fabrication and erection was achieved in five months; three months less than the estimated conventional 'design, detail, tender, award, fabricate, erect' approach.

The design team consulted Network Rail throughout the development of the structure. Based on the fabricator's experience the team proposed the use of perforated steel plate on the inside face of the truss to form a non-climbable parapet over the railway and Network Rail approved this. This has achieved a more 'open feel' to pedestrians using the bridge and also enhanced the aesthetics (Fig. 6). This solution complies with

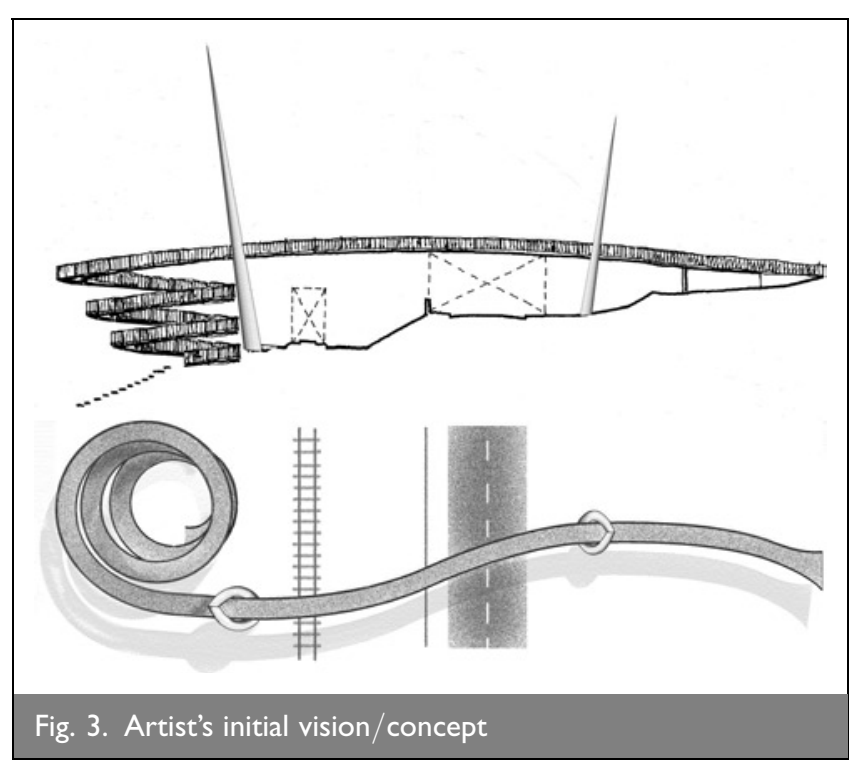




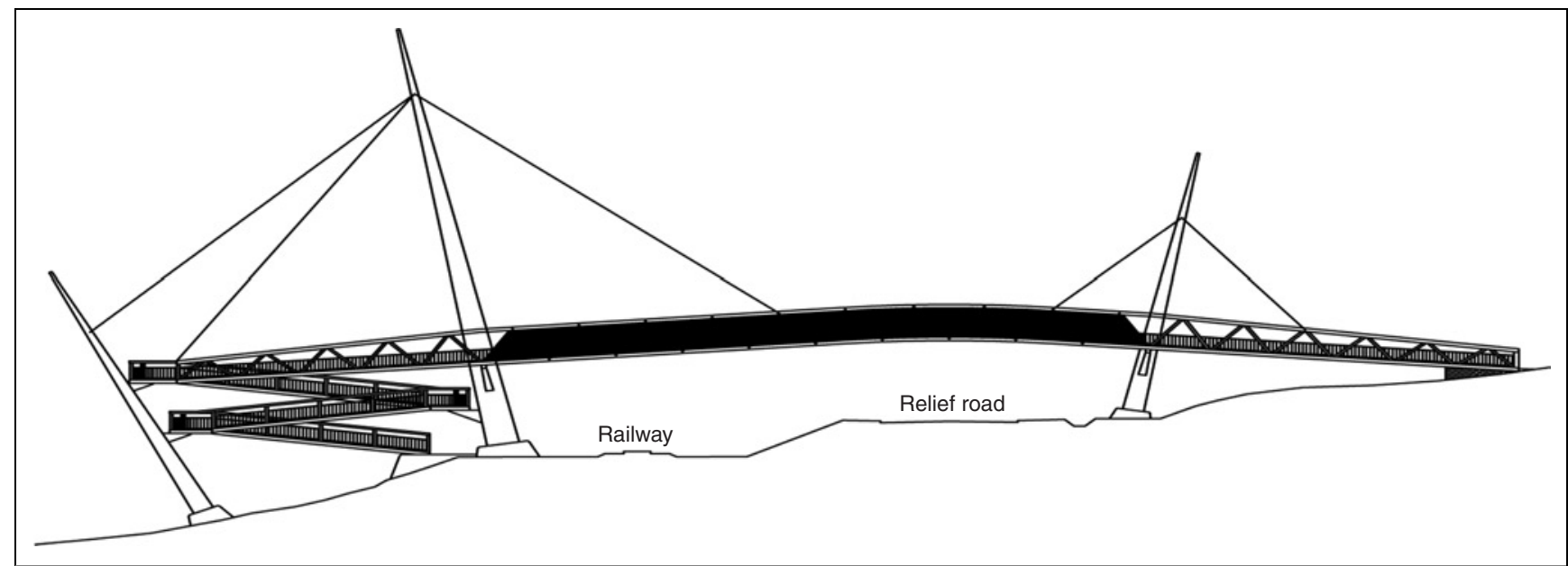

Fig. 4. Initial landmark structure design following design review of artist's concepts

the interim requirements for road restraint systems ${ }^{1}$ and exceeded the artist's expectations while keeping within the available funds.

No canopy or enclosure was provided over the railway. However, steel plates were welded to the top chord of the truss to enable enclosures to be bolted on in the future, if required. The artist designed an enclosure to suit the form of the structure and this was archived for future reference.

The footbridge supports were located outside the railway 'hazard zone' and were not designed for collision loading. The eastern column was positioned more than $4.5 \mathrm{~m}$ away from the new carriageway and a $5.3 \mathrm{~m}$ headroom clearance was provided. The implication of this was that the column was not designed for impact loading but the deck was designed to be self-supporting should the column be completely demolished by vehicular impact.

\section{DESIGN ISSUES}

The detailed design was undertaken in accordance with the technical approval procedures stated in $\mathrm{BD} 2 / 02{ }^{2}$ The main design reference document was Department for Transport BD29 $/ 87^{3}$ and BD29/03 was also considered following its introduction towards the end of the project.
The superstructure comprises a three-span truss supported on steel columns with approach ramps on the western side. The longest span crosses both the railway and the new single carriageway relief road. The superstructure was analysed using a three-dimensional space-frame model to determine the interaction of the truss with the columns and the cables under applied loading.

Although the cables appear to support the deck, the main mast above deck level and the stay cables are mainly 'cosmetic' but they contribute significantly to the unique profile of the bridge. Some loading will be imposed on the structure by the self-weight and catenary of the cables. This loading has been taken into account in the design.

The triangular main mast is inclined in two planes. This presented difficult three-dimensional setting out and detailing problems for the construction of the mast and reinforced concrete base. The transfer of information from the fabricator's three-dimensional (3-D) Xsteel CAD program to the substructure designer's AutoCAD package eased this problem. The fabricator's 3-D drawings were also particularly useful for discussing fabrication details within the design team.

The artist created a 3-D CAD drawing of the structure to superimpose the proposed lighting system and paint colours on

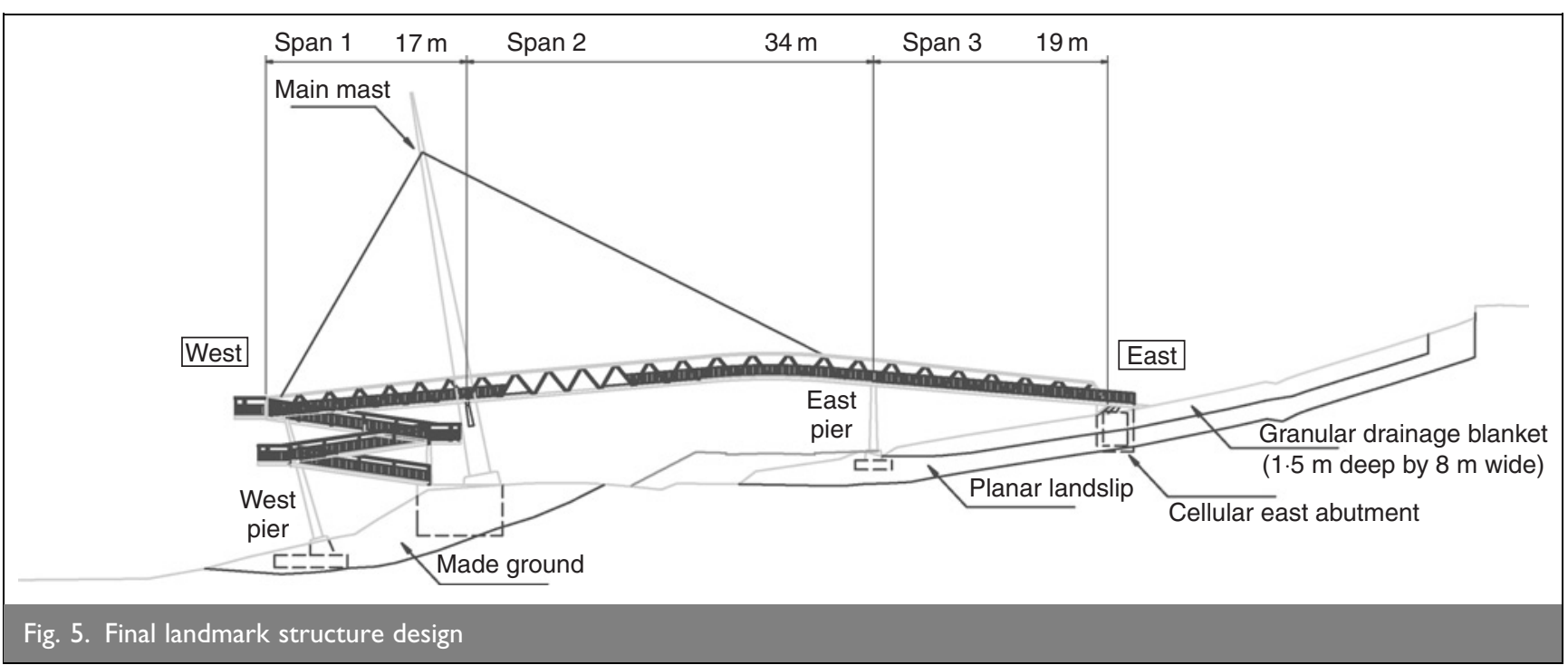




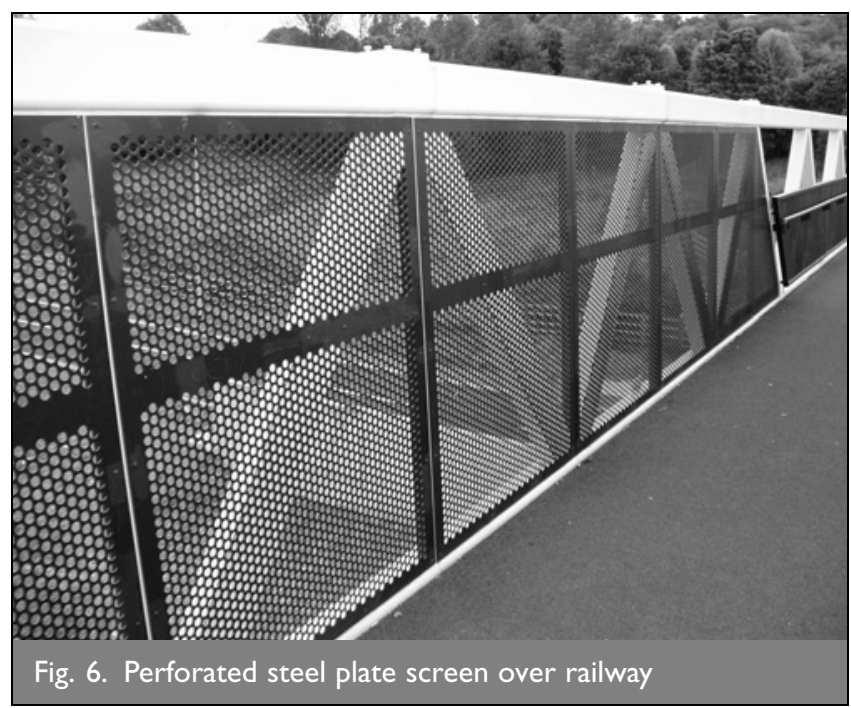

to the structure. This assisted colour selection for the structure and paint sample test boards were also produced to confirm the proposed colour scheme. The client approved the proposed colour scheme based on the images and samples supplied by the artist. Although no feature lighting has been provided to this structure as yet, brackets have been provided on the structure to allow future lighting systems to be bolted on. All fabrication details were agreed with the artist prior to the manufacture. He was involved, therefore, in the fabrication process from inception to completion.

As the design progressed, the design team developed the following details to enhance the appearance of the bridge.

(a) The truss varies in depth to achieve optimum architectural form for the structure.

(b) Bolted connections, where used, have been carefully detailed to minimise their visual impact. A 3-D image of the structure was developed to ensure that the inclined cables did not conflict with the pedestrian clearance envelope.

(c) The parapet/handrail sections, connections and colour were chosen to enhance the appearance of the structure; the darker blue colour of the parapets emphasise the form of the truss.

(d) Semicircular landings have been detailed on the western stepped access ramps (Fig. 2); this has provided a particularly attractive form.

(e) The cable connection detail with the main mast and truss was developed using the Xsteel program; this ensured that there was sufficient room to accommodate the cables and turnbuckles at the connections.

( $f$ ) A wider deck than required by BD29 was provided to achieve a more 'open' feel to the structure to encourage its use by the public.

For the substructure design additional ground investigation was required at the site due to the change in form of the footbridge. The new east abutment was to be built within a translational landslip. Made ground was anticipated under the foundations of the main mast and western pier on the railway embankment (Fig. 5).

Following assessment of the additional ground investigation information the design team used the main mast to fix the superstructure in its longitudinal direction. Stability analysis was undertaken to determine the effect of the main mast foundation loads on the railway embankment and the foundation level was determined accordingly. The free end at the eastern abutment accommodates deck movements due to temperature effects and soil movements.

The east abutment design had to take into account a layer of very weak clay, $3 \mathrm{~m}$ in depth, below ground level. In addition there was evidence of potential slope failure. The geotechnical engineers advised that, as this was a landslip area, any additional loading of the slope was likely to cause failure. The design solution was to construct a hollow cellular abutment at the eastern end to reduce the loading on the landslip. The high water table was lowered by replacing the soft clay with a granular drainage blanket, $1.5 \mathrm{~m}$ deep by $8 \mathrm{~m}$ wide, that connected to a positive drainage outlet (Fig. 5). In addition to increasing the slope stability the replacement of the clay with the drainage blanket also allowed access on to the eastern slope for construction of the east abutment.

\section{FABRICATION AND ERECTION}

The fabricator's experience was particularly valuable during the erection phase. The fabricator designed a cradle to support the holding-down bolts during construction of the complex reinforced concrete base for the main mast and for the erection of the main mast itself. Part of the main mast concrete base was cast and the cradle was bolted on to this first lift. The cradle was then cast into the reinforced concrete base and plinth to hold the bolts securely in position. Adjustment bolts were also provided on the cradle to accurately locate the $30 \mathrm{~m}$ high, $15 \mathrm{t}$ mast during erection. The use of varying length holding-down bolts allowed easier engagement of the bolts within the main mast base plate.

The involvement of the fabricator during the design process ensured that a buildable structure was achieved and that the artist's requirements were fully considered. In March 2004 the reinforced concrete foundations were completed and the deck erected on time and within the available budget.

\section{DISABILITY DISCRIMINATION ACTAND DISABLED ACCESS}

The bridge replaced an existing structure and provides access across a steep valley; the gradient across the site is approximately 1 in 5 . BD29/04 states that 'ramps for pedestrians shall not be steeper than 1 in 20 unless agreed otherwise with the Overseeing Organisation. ... However no ramp shall be steeper than 1 in 12'. A $450 \mathrm{~m}$ length of ramp would have been required to accommodate the 1 in 20 gradient through this area. It was impractical to provide a fully Disability Discrimination Act (DDA)-compliant structure at this location although every 'reasonable' step was taken to maximise disabled access over this structure.

The new deck provides 1 in 12 ramps on spans 1, 2 and 3 (Fig. 5). The stepped ramp access on the western approach gives an effective gradient of 1 in 7 although the gradient on the steps is 1 in 12. The project team considered a full range of factors in reaching the final solution and access provision including: modes 
of users; aesthetics; environmental impact of the proposals; the cost of the landmark structure compared with the available budget; robustness of the design; buildability, operation and maintenance. Based on these factors, this landmark footbridge provides a compromise solution at this particular site.

As the topography made it extremely difficult to provide the desired disability gradients at this site, an access consultant selected from the National Register of Access Consultants undertook an access audit and prepared an access statement for this footbridge.

The author refers the reader to Department for Transport publication Inclusive Mobility together with British Standard BS 8300 and BS 5395 for guidance on the provision of disabled access on infrastructure schemes. ${ }^{4-6}$ The guidance given above may help designers when considering whether they have made 'reasonable' provision for disabled access under the Disability Discrimination Act.

\section{CONCLUSION}

The paper describes the design processes that were followed to create a landmark structure. Regular effective communication throughout the team, drawing on the creative flair of the artist and practical expertise of contractor and fabricator, has resulted in a striking landmark structure being delivered for the Ebbw Valley. The creation of a project framework at the inception, allowing for the integration of the artist and gaining the full cooperation of the project partners, ensured a smooth-running, fast-track project. A high-quality piece of urban infrastructure has been achieved with the inclusion of an artist in the planning and design teams. This was all achieved within tight time and budget constraints.

\section{ACKNOWLEDGEMENTS}

The author would like to acknowledge the client, Blaenau Gwent County Borough Council, for permission to publish this paper. The contribution of the project partners (reported in Table 1), to the successful delivery of this landmark structure is also acknowledged.

\section{REFERENCES}

1. Highways Agency. Interim Requirements for Road Restraint Systems (IRRRS). Highways Agency, London, 2004.

2. Department for Transport. The Technical Approval of Highway Structures. Design Manual for Roads and Bridges. Her Majesty's Stationery Office, London, 2002, BD2/02.

3. Department for Transport. Design Criteria for Footbridges. Design Manual for Roads and Bridges. Her Majesty's Stationery Office, London, 2004, BD29/87, BD29/03, BD29/04.

4. Department for Transport. Inclusive Mobility-a Guide to Best Practice on Access to Pedestrian and Transport Infrastructure. Department for Transport, London 2002.

5. British Standards Institution. Design of Buildings and their Approaches to Meet the Needs of Disabled People-Code of Practice. BSI, London, 2001, BS 8300.

6. British Standards Institution. Code of Practice for the Design of Straight Stairs. BSI, London, 2000, BS 5395.

\section{What do you think?}

To comment on this paper, please email up to 500 words to the editor at journals@ice.org.uk

Proceedings journals rely entirely on contributions sent in by civil engineers and related professionals, academics and students. Papers should be $2000-5000$ words long, with adequate illustrations and references. Please visit www.thomastelford.com/journals for author guidelines and further details. 